$$
\begin{aligned}
& 627.132 \\
& F 2 \text { s }
\end{aligned}
$$

- FINAL REPORT

\title{
EVALUATION OF STREAM IMPROVEMENTS
}

ON

PRICKLY PEAR CREEK

$1971-1973$

$$
\begin{aligned}
& \text { F-9-R-19 - Job II-a } \\
& \text { F-9-R-20 - Job II-a } \\
& \text { F-9-R-21 - Job II-a } \\
& \text { F-9-R-22 - Job II-a }
\end{aligned}
$$

\section{Financed by}

Montana State Fish and Game Commission

and

Montana State Highway Commissión

The opinions, findings and conclusions expressed in this publication are those of the author and not necessarily those of the Montana State Fish and Game Commission or those of the Montana State Highway Commission. This publication includes material in addition to that called for in contract agreements, specifically discussions on fish populations and erosion control. 


\section{ABSTRACT}

Willow shoot plantings were made in May, 1968 to reestablish woody streamside vegetation which had been removed in the relocation of a portion of the Prickly Pear Creek channel during the construction of Interstate Highway 15. Sixty-one percent of the willows planted in double rows survived the first summer and twenty-six percent of those planted in single rows survived. In 1969, evaluation of the plantings indicated further losses resulting in poor success overall because of unstable soil and heavy losses due to bank erosion.

In Apri1, 1971, rock and soil berms were constructed at the toe of four steep eroding banks to stop streambank sloughing along the relocated channel of Prickly Pear Creek. The berms were used in shrub experiments to test the survival of naturally occurring species, when transplanted to reestablish streambank vegetation.

The survival of naturally occurring shrubs was tested from spring plantings and summer plantings. In addition, survival was compared from different treatment of the plants. The best results were obtained from spring-planted horizontal (see text) willows (Salix sp.) with 70.2 percent of the 84 planted surviving the first summer. Spring plantings of vertical willow and dogwood (Comus stolonifera) had survival rates of 38.0 and 12.5 percent respectively. During the first summer, survival of summer transplants was not satisfactory. Common snowberry (Symphoricampos albus) proved to be the most successful among the rooted stock transplanted to the back slopes adjacent to each berm. Spring was the most favorable time of year for these transplants.

Blanket riprap was used to protect the highway grade from stream erosion. Willow (Salix sp.) shoots were planted in the spaces between the large rocks at the water level to speed up the revegetation process. In the spring of 1971, 100 shoots were planted on two riprap sections. In the spring of 1973, an additional 182 shoots were planted in the same area. In December 1973, 167 shoots remained alive in the two areas. A third area had been left to natural seeding and only three live willows were present.

Natural seeding in areas where good soil quality existed accounted for reestablishing dense vegetation on the berms and back slopes of the experimental areas.

Fish population estimates in 1972 indicated that trout numbers returned to preconstruction (1967) levels with 79 rainbow trout (Salmo gairaneri) and 90 brown trout (Salmo trutta) per acre. The total pounds of trout (30 pounds per acre) was still below preconstruction levels (36 pounds per acre). Sucker (Catostomus catostomus and Catostomus cormersoni) populations remained at a level 59 percent below the preconstruction numbers.

\section{BACKGROUND}

A study was initiated on Prickly Pear Creek in 1965 to document the condition of the fishery and stream channel prior to construction of Interstate Highway 15 seven miles south of Helena. A continuous 3,300-foot channel change was proposed for Prickly Pear in that area. To mitigate the loss of natural channel, the stream was artificially meandered in the floodplain to retain its original length. Prior to construction, the average depth and 
width were 1.4 and 26.4 feet, respectively, and spacing of successive pools was every 6.6 times the average stream width, or a pool every 180 feet (Elser, 1969). No effort was made, during the construction of the new channel, to duplicate the physical parameters of the natural channel except length.

Preconstruction fish population estimates indicated that suckers made up 62. 1 percent of the tota 1 number and 78.6 percent of the total weight. Trout comprised 37.9 and 21.5 percent of the total numbers and weight, respectively. Rainbows were the most abundant trout species (Elser, 1968).

Physical parameters were measured in three post-construction years, 1968, 1969 and 1970. Fish populations were measured in five post-construction years, 1968 through 1972. The man-made channel was three percent longer than the natural channel it replaced (3150 to 3250 feet). Construction reduced average width, depth and thalweg depth by four percent (26 to 25 feet), 28.6 percent ( 1.4 to 1.0 feet) and 21.7 percent ( 2.3 to 1.8 feet), respective1y. These figures remained unchanged through 1968, 1969 and 1970, except for a slight increase in average thalweg depth (1.9 to 2.0 feet) in 1970 . The pool riffle periodicity has undergone adjustment toward the 6.6 stream widths of the original channel. In 1968, the first year after construction, spacing was 15.7 widths or a pool every 380 feet. The periodicity had adjusted to 8.8 widths in 1969 and 7.8 widths (a pool every 196 feet) in 1970 (E1ser, 1971).

The sucker:trout ratio of $2: 1$ by numbers and $3: 1$ by weight remained unchanged immediately following construction; however, brown trout became the most abundant game fish in weight and numbers per acre in 1968, whereas rainbow trout predominated in 1967 (E1ser, 1971). The most significant change in the fish population came in a reduction of the total standing crop. Numbers and weight of fish per acre were reduced by 45.8 percent (432 to 234) and 51.2 percent ( 168 to 82 pounds per acre), respectively, between 1967 and 1968 . Population estimates in 1969 were 228 fish per acre weighing 78 pounds.

Woody vegetation which existed in the area of the new Prickly Pear Creek channel was removed during construction and banks of the new channel were left steep and easily erodable. In May, 1968, willow shoots were planted along 3,018 feet of disturbed streambank in an effort to reestablish the woody vegetation which had been lost. Evaluation of the 1968 shoot plantings showed that willows planted in double rows had 61 percent survival and those planted in single rows had 26 percent survival over the first summer (Elser, 1969). In 1969, evaluation of the plantings indicated further losses resulting in poor success overal1 because of unstable soil and heavy losses due to bank erosion (Elser, personal communications). This report describes an experimental method employed to halt bank sloughing and to enhance the recovery of streamside vegetation along the man-made channel of Prickly Pear Creek.

\section{OBJECTIVES}

The Prickly Pear Creek Study from 1971 to 1973 included the following:

1. Experimentation with rock and soil berms as a method of controlling streambank erosion.

2. Determination of which naturally occurring shrub species can be successfully transplanted to speed up revegetation of a denuded area. 
3. Estimation of fish population numbers in the area affected by construction.

\section{PROCEDURES}

In 1971, a front-end loader was used to pick up rock and soil in areas of severe bank erosion and construct low, flat berms along the water's edge at the toe of four of the eroding banks. Rocks were placed along the face of each berm to keep it from washing away. The banks were then sloped with a tractor-mounted backhoe.

Shrub experiments were conducted on the surface of the berms and back slopes. The berms ranged in length from 36 to 146 feet long. Berms 1 and 2 (see map) were divided into experimental plots of 60 square feet each; berms 3 (136 sq. ft.) and 4 (72 sq. ft.) were not divided. Each plot received a different species or treatment of a species to be evaluated. Treatements consisted of spring plantings, summer plantings, vertical or horizontal shoot cuttings and rooted stock. Eight of the 14 experimental plots were planted prior to spring runoff, and six were planted in early summer, after all plants were fully leafed. Horizontal shoot cuttings consisted of an eight- to teninch section of main stem including one branch. The section of main stem was laid in a trench and covered with soil so that the branch protruded from the soil. Vertical shoot cuttings were taken from branches which had soft pliable bark and a terminal bud. Cuts were made at a $45^{\circ}$ angle to expose a large surface area to the soil for root production. A steel rod was used to make a hole in the soil as deep as possible (12 to 18 inches) to prevent damaging the cut end of the shoot (Jensen, 1971).

Outside bends along the toe of the highway grade were riprapped during construction to control erosion. Soil was placed in the interstices between large rocks to provide a place for experiments with revegetation of a largerock riprap area.

Fish populations were sampled using 0-500 variable voltage direct current electrofishing equipment and the population estimates were made by the mark and recapture method. Procedures used in population sampling and data analys is are described by Vincent (1971).

Stream flow measurements were not made; stream flows appeared to be more or less normal during the period of this study.

\section{FINDINGS}

\section{Erosion Contro1}

Artifically meandering the new channel so as to retain original channel length alleviated erosion problems. Observations up and down stream from the alterations have disclosed no changes in the erosion and deposition patterns outside the study area.

After construction was completed, erosion began in some of the areas of the new channel where riparian vegetation had been destroyed and where the banks had been left unprotected. Berms were constructed before spring runoff at the toe of each of four banks. Bank heights before berm construction, length and amount of material used in each berm are shown in Table 1. To facilitate sloping, the creek bank adjacent to berm 1 (Figure 1) was cut 


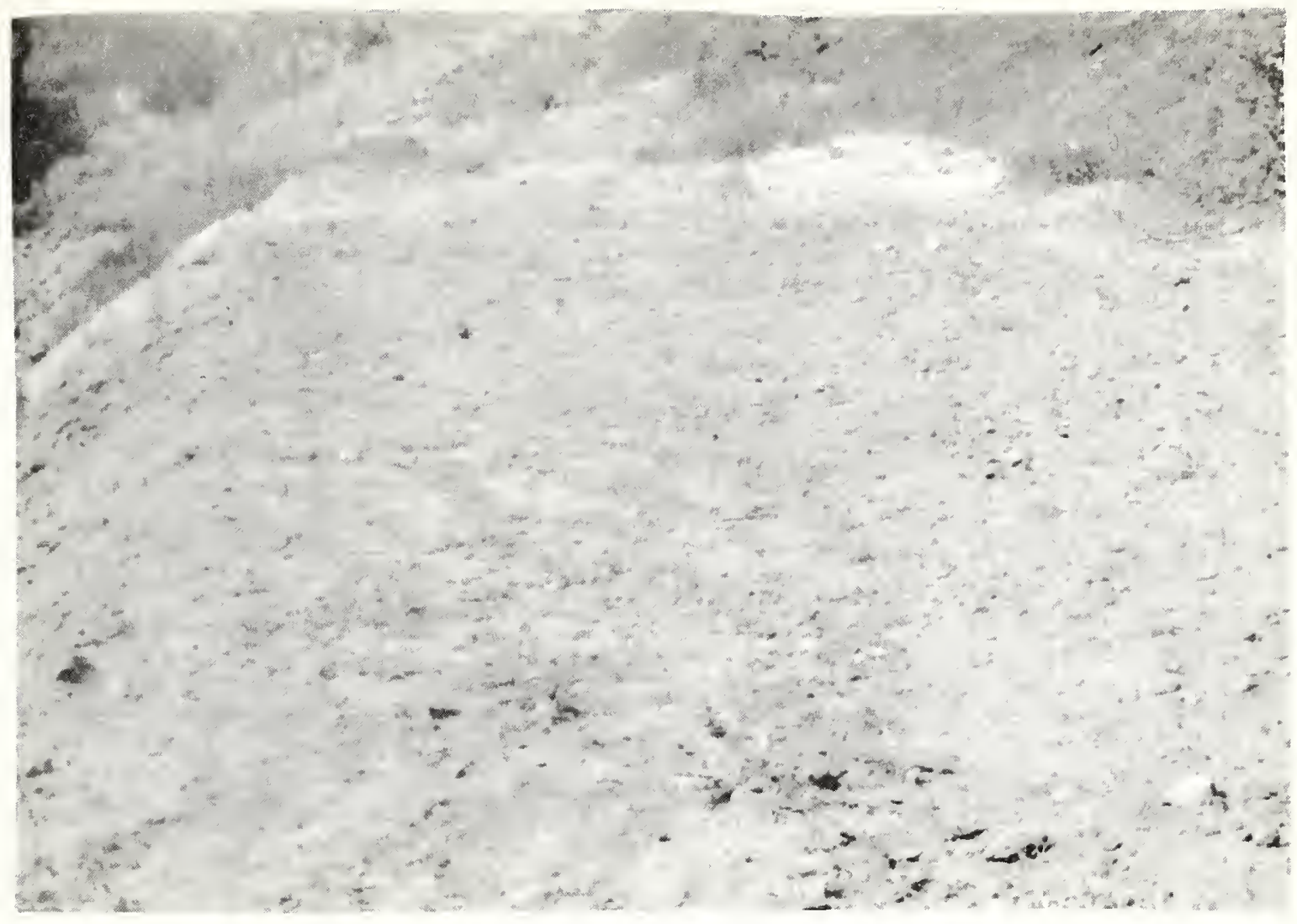

Figure 1. Top bank along berm one in the summer of 1971.

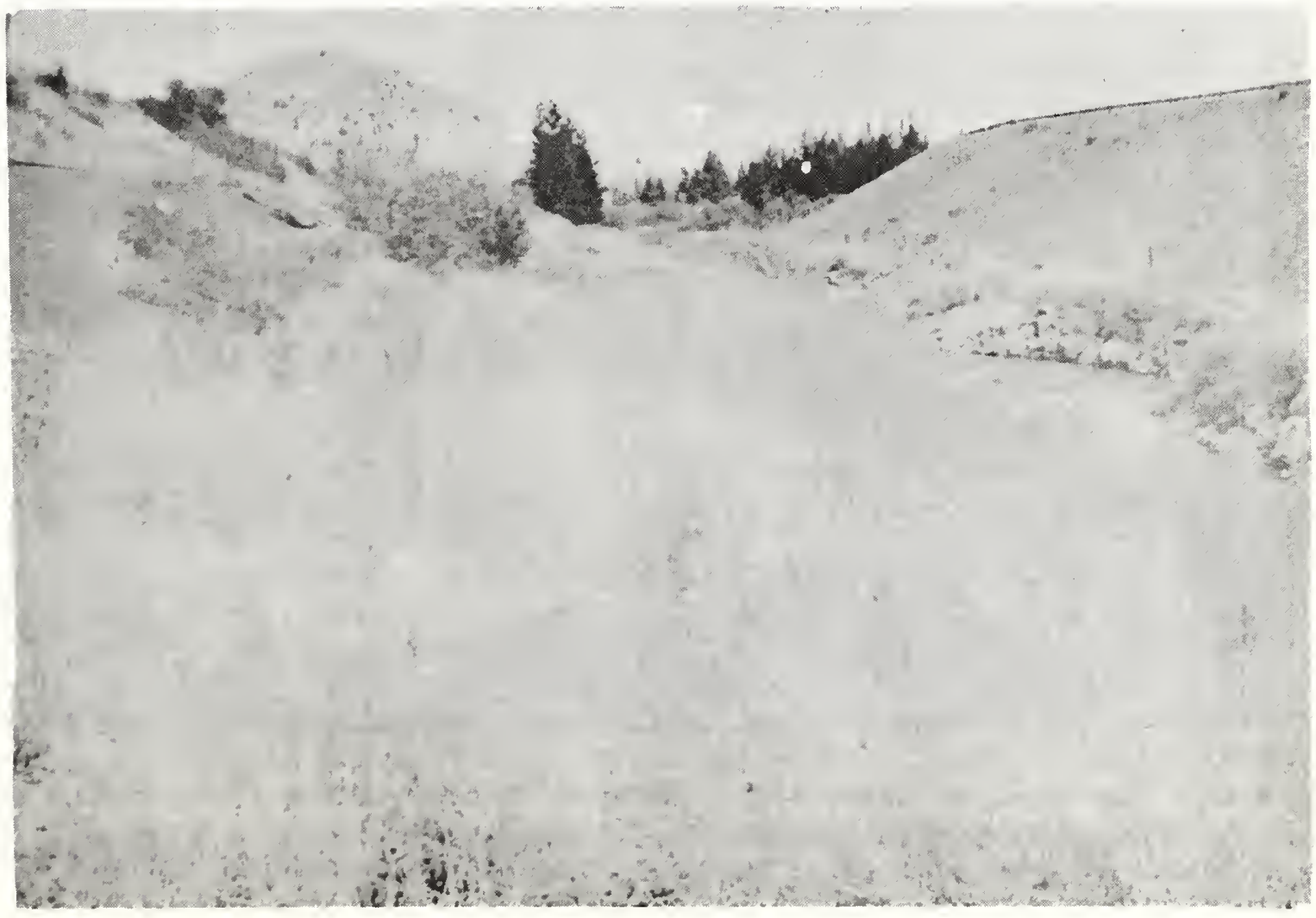

Figure 2. Top bank along berm one in the summer of 1972. 
down to about eight feet high and leveled, bank 2 was cut to six feet high and leveled, banks 3 and 4 were left at their original heights. Berms were inundated during the 1971 spring runoff. Some soil was lost; however, no substantial damage was evident and the berms were successful in stopping further sloughing of the once steep banks. The technique has had at least four positive effects: (1) soil has been stabilized; (2) natural invasion of wild plants has been enhanced; (3) stable areas were provided for transplanting wild plants to speed up the revegetation process; and (4) aesthetics of natural streambanks were preserved to a greater extent than if blanket riprap had been used.

TABLE 1. Bank and berm measurements for four experimental areas on Prickly Pear Creek

\begin{tabular}{cccc}
\hline $\begin{array}{l}\text { Area } \\
\text { Number }\end{array}$ & $\begin{array}{l}\text { Bank } \\
\text { height } \\
\text { (feet) }\end{array}$ & $\begin{array}{l}\text { Berm } \\
\text { length } \\
\text { (feet) }\end{array}$ & $\begin{array}{l}\text { Berm } \\
\text { material } \\
\text { (cubic yards) }\end{array}$ \\
\hline 1 & $4-12$ & 146 & 75 \\
2 & $4-10$ & 100 & 52 \\
3 & 13 & 68 & 17 \\
4 & 13 & 36 & 13 \\
\hline
\end{tabular}

\section{Vegetation}

Berms were built so that water from the stream would percolate into the soil and provide shoot cuttings and grass seed with adequate moisture.

A total of 213 native willow (Salix sp.) and 80 dogwood (Cornus stolonifera) shoots were planted on the berms prior to the 1971 spring runoff. An inventory, taken August 25, 1971, indicated that the best survival was among the springplanted horizontal willows (70.2 percent). Survival rates for spring-planted vertical willow and dogwood were 38.0 percent 13.8 percent respectively (Table 2).

Summer plantings were made to test survival of the same species as tested in the spring. Survival was again highest among horizontal willow (17.2 percent). Vertical willow and dogwood survival rates were 13.1 percent and 0 percent, respectively (Table 2 ).

Rooted shrubs were planted along the end of the top bank adjacent to each berm. Common snowberry transplanted in the spring proved the most successful with a survival rate of 63.0 percent. Rose was second with 31.6 percent surviving the summer. All dogwood and chokecherry plants died. Common snowberry was the only species transplanted on the back slopes in early summer; none of them survived.

The natural revegetation in the study areas seemed to be controlled by soil quality, once the soil stabilized (Figures 2 and 3 ). The soil in study area 1 consisted of sandy loam. Proceeding downstream, study area 2 was mostly clay which became hard and impermeable during the summer. Areas 3 and 4 were composed of clay with large amounts of partially decomposed granite (Figure 4 ). 

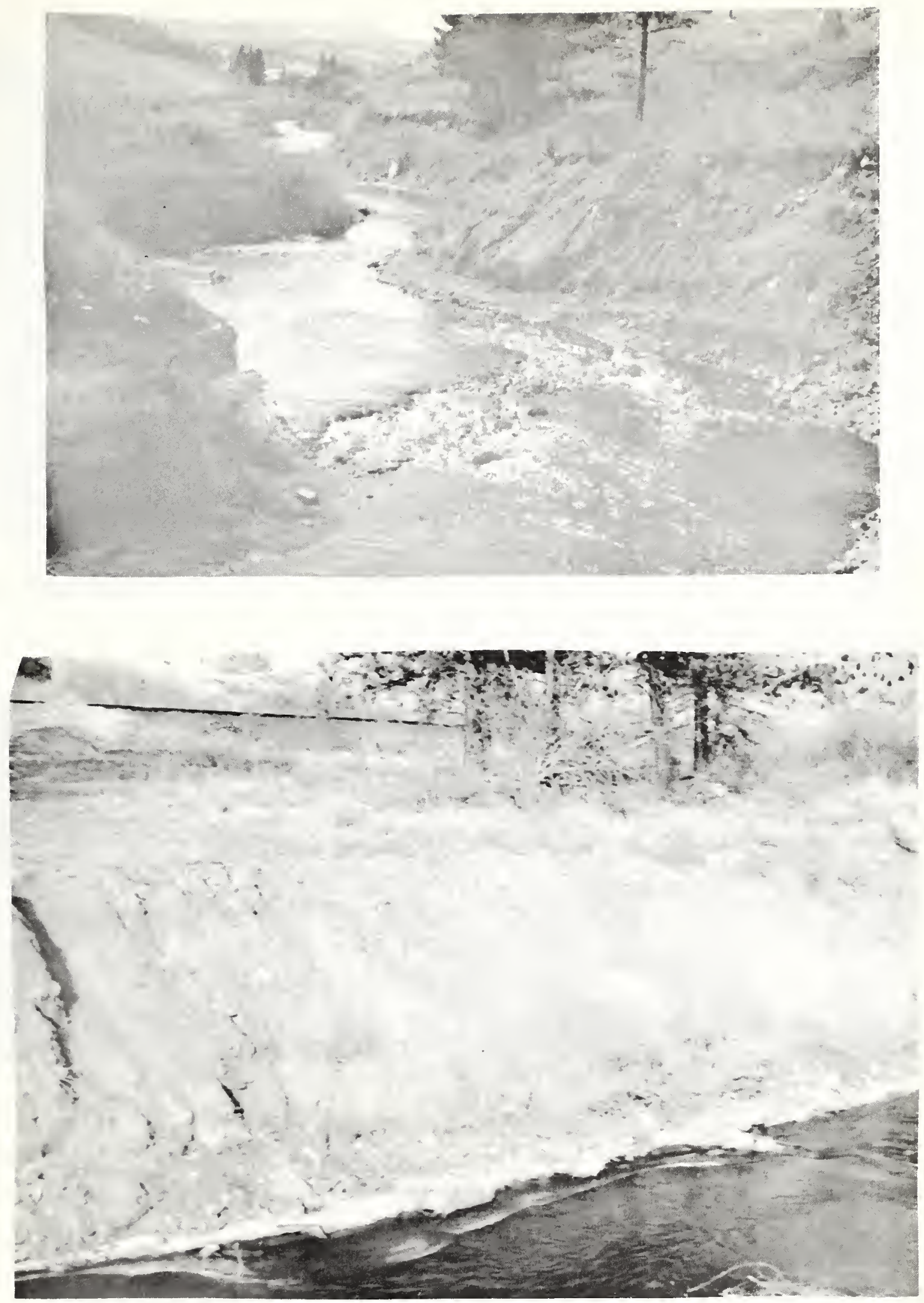

Figure 3. Berm 3 (above) and berm 4 (below) in the summer of 1972 

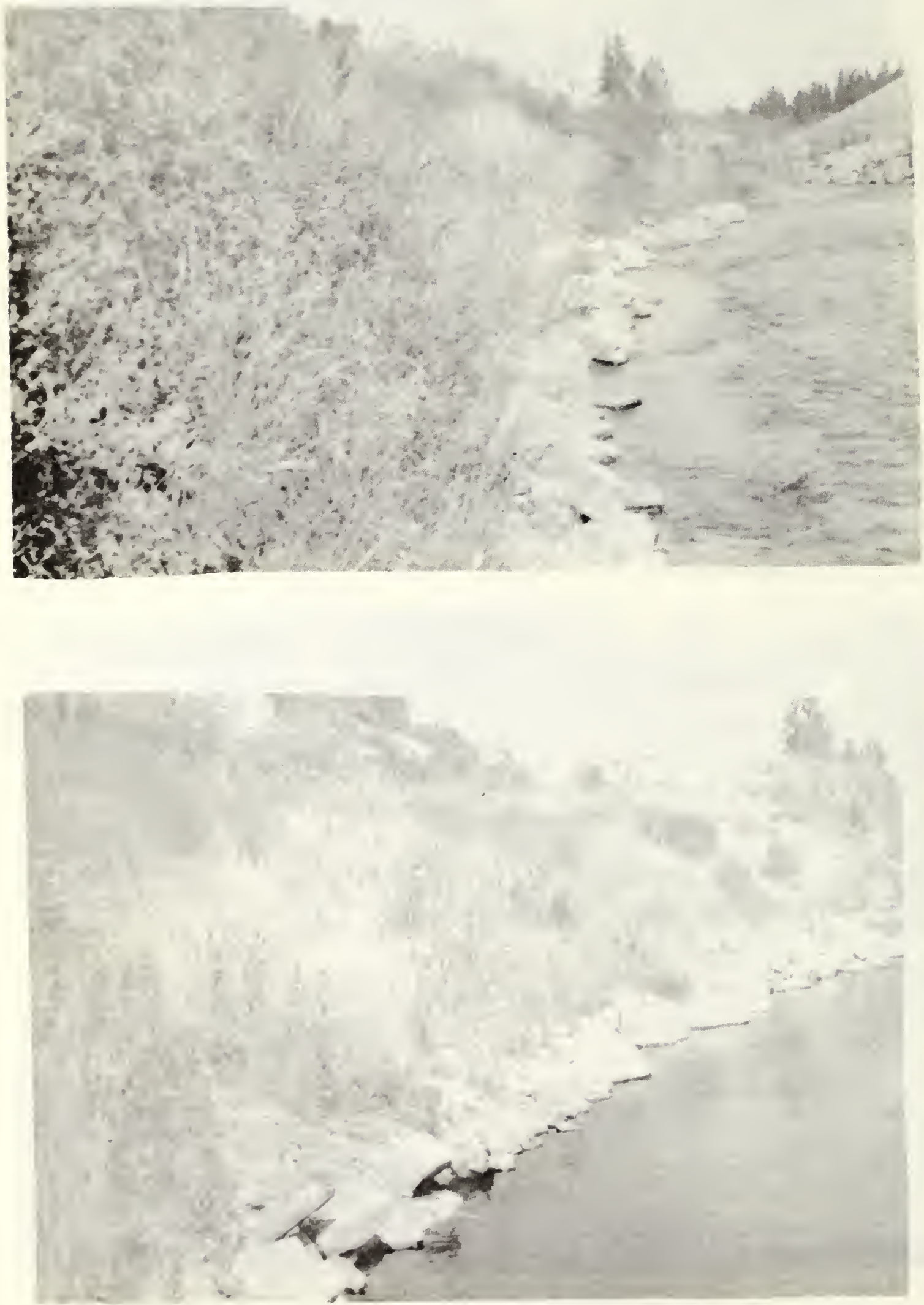

Figure 4. Study area one (above) and area two (below) in the summer of 1972. 

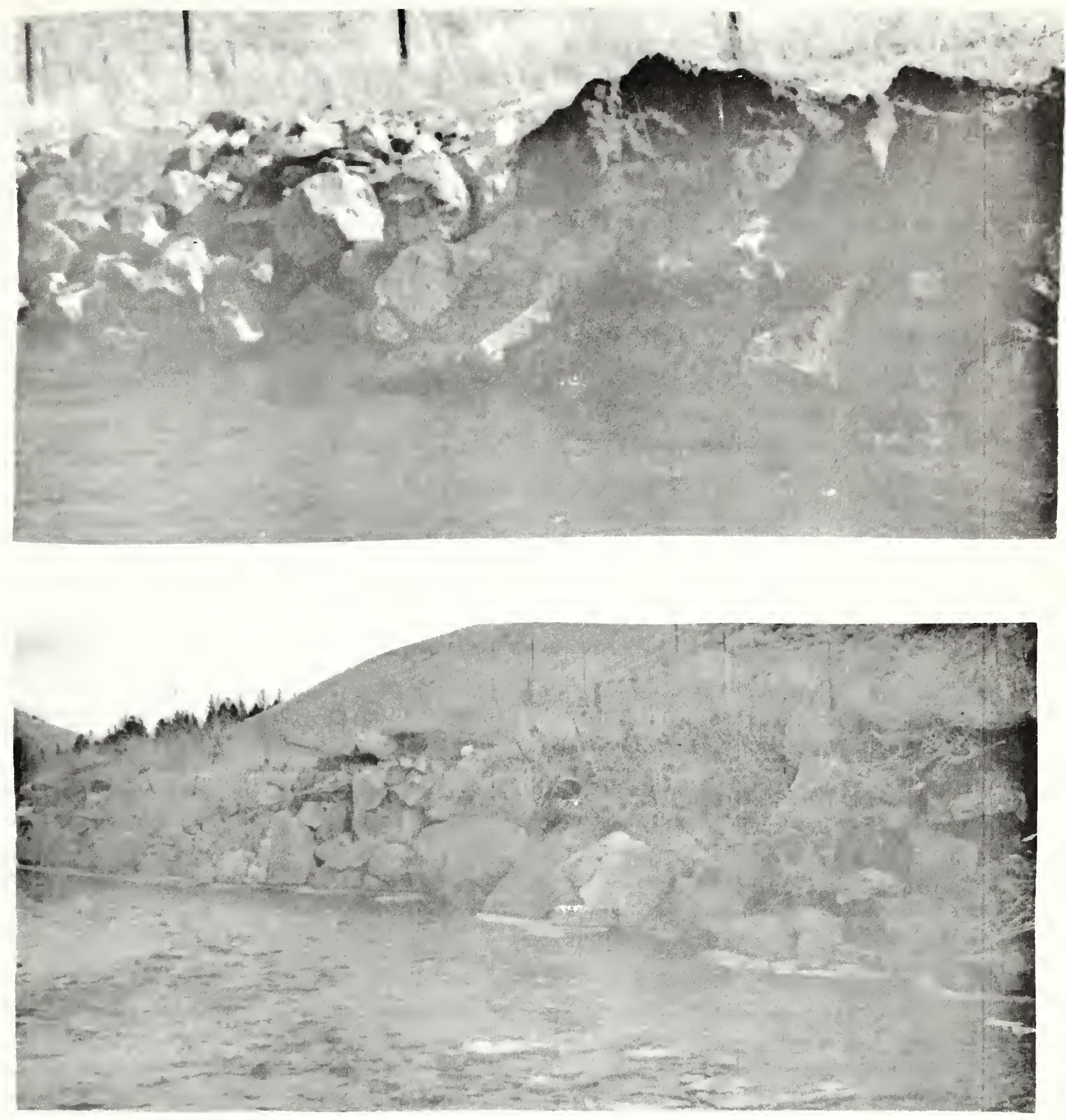

Figure 5. Rip-rap area B (above) in 1971 before completely covered with soil. Rip-rap area B (below) in 1972. 
TABLE 2. Number of each species and treatment planted in Apri1, 1971 on the berms and numbers surviving until August, 1971, with percent surviving in parentheses.

\begin{tabular}{|c|c|c|c|c|c|c|c|}
\hline \multirow{2}{*}{\multicolumn{2}{|c|}{ Berm }} & \multicolumn{2}{|c|}{$\begin{array}{c}\text { Vertical Willow } \\
\text { planted in } \\
\end{array}$} & \multicolumn{2}{|c|}{$\begin{array}{l}\text { Horizontal Willow } \\
\text { planted in } \\
\end{array}$} & \multicolumn{2}{|c|}{$\begin{array}{c}\text { Dogwood } \\
\text { planted in }\end{array}$} \\
\hline & & Spring & Summer & Spring & Summer & Spring & Summer \\
\hline 1 & $\begin{array}{l}\text { Planted } \\
\text { Surviving }\end{array}$ & $\begin{array}{l}50 \\
19(38)\end{array}$ & $\begin{array}{l}80 \\
17(14)\end{array}$ & $\begin{array}{l}32 \\
26\end{array}(81)$ & $\begin{array}{l}32 \\
11(34)\end{array}$ & $\begin{array}{l}30 \\
10(33)\end{array}$ & $\begin{array}{r}25 \\
0(0)\end{array}$ \\
\hline 2 & $\begin{array}{l}\text { Planted } \\
\text { Surviving }\end{array}$ & $\begin{array}{l}50 \\
16(32)\end{array}$ & $\begin{array}{r}50 \\
6(12)\end{array}$ & $\begin{array}{l}32 \\
24(75)\end{array}$ & $\begin{array}{r}32 \\
0\end{array}$ & $\begin{array}{r}50 \\
0(0)\end{array}$ & \\
\hline 3 & $\begin{array}{l}\text { Planted } \\
\text { Surviving }\end{array}$ & $\begin{array}{l}29 \\
14 \text { (48) }\end{array}$ & & & & & \\
\hline 4 & $\begin{array}{l}\text { Planted } \\
\text { Surviving }\end{array}$ & & & $\begin{array}{r}20 \\
9(45) \\
\end{array}$ & & & \\
\hline & tals & $\begin{array}{r}129 \\
49(38.0)\end{array}$ & $\begin{array}{r}130 \\
17(13.1)\end{array}$ & $\begin{array}{l}84 \\
59(70.2)\end{array}$ & $\begin{array}{l}64 \\
11(17.2)\end{array}$ & $\begin{array}{l}80 \\
10(12.5)\end{array}$ & $\begin{array}{r}25 \\
0\end{array}$ \\
\hline
\end{tabular}

In the summer of 1972 and 1973, vegetation from natural seeding was so dense in areas of good soil quality (areas 1 and 2) that it became impossible to inventory the experimental plants (Figure 4).

Blanket riprap was placed on the outside bends of the new channel to protect the highway grade (see map). In 1971, a mixture of loam and clay soil was placed on three riprap areas and worked into the spaces between the rocks; however, this soil washed away except for that above the water 1 ine (Figure 5 ). Also, in 1971, native willow shoots were planted in spaces protected from the direct force of high water in moist soil deposited by the stream near low water level.

Fifty native willow shoots were planted on each of riprap areas $A$ and $B$ (114 and 146 feet 1ong, respectively). Area C (140 feet 1ong) was left to natural seeding. In April, 1973, an additional 62 and 120 willow shoots were planted on riprap $A$ and $B$, respectively. In December, 1973, 91 willows were still surviving on Area A, 76 on Area B and only 3 could be found on Area C which had been left for natural seeding. The apparent high degree of success of these transplanted willows can be attributed to the abundance of moisture in the soil adjacent to the stream at water level and to the time of year they were planted (April). As these willows grow and become more dense, water velocity among them will be slowed enhancing the chances of filling the spaces with soil through natural deposition. The value in placing soil on the riprap was that natural seeding was enhanced in the soil which remained above the high water mark after spring runoff (Figure 5).

\section{Fish Population}

After highway construction was completed in 1968, fish populations remained at a level approximately 50 percent less than preconstruction (1967) until 1971 when a 45 percent increase (comparing 1970 to 1971) was seen in 
trout numbers. An increase of 50.0 percent was seen in the trout population numbers between 1971 and 1972 (Table 3). This brought the total trout population numbers up to essentially the same as the preconstruction population.

TABLE 3. Estimated fish populations for Prickly Pear Creek, pre- (1967) and post-construction (1968, 1969, 1970, 1971, 1972), expressed as numbers of Age I and older fish per acre, with pounds per acre in parentheses. Confidence intervals at $80 \%$ level for the number estimates.

\begin{tabular}{|c|c|c|c|c|c|c|}
\hline Species & 1967 & 1968 & 1969 & 1970 & 1971 & 1972 \\
\hline Rainbow Trout & $\begin{array}{c}98 \\
(12)\end{array}$ & $\begin{array}{l}31 \\
(4)\end{array}$ & $\begin{array}{l}19 \\
(4)\end{array}$ & $\begin{array}{l}37 \\
(5)\end{array}$ & $\begin{array}{l}47 \\
(5)\end{array}$ & $\begin{array}{l}79 \\
(13)\end{array}$ \\
\hline Brown Trout & $\begin{array}{c}61 \\
(24)\end{array}$ & $\begin{array}{c}47 \\
(13)\end{array}$ & $\begin{array}{c}55 \\
(15)\end{array}$ & $\begin{array}{c}41 \\
(11)\end{array}$ & $\begin{array}{l}66 \\
(9)\end{array}$ & $\begin{array}{c}90 \\
(17)\end{array}$ \\
\hline Longnose Sucker & $\begin{array}{c}234 \\
(125)\end{array}$ & $\begin{array}{l}128 \\
(59)\end{array}$ & $\begin{array}{l}747 \\
(53)\end{array}$ & * & $\begin{array}{l}116 \\
(59)\end{array}$ & $\begin{array}{l}112 \\
(53)\end{array}$ \\
\hline White Sucker & $\begin{array}{l}39 \\
(7)\end{array}$ & $\begin{array}{l}28 \\
(6)\end{array}$ & $\begin{array}{c}7 \\
(6)\end{array}$ & * & * & * \\
\hline Total Trout & $\begin{array}{l}159 \\
(36)\end{array}$ & $\begin{array}{l}78 \\
(17)\end{array}$ & $\begin{array}{c}74 \\
(19)\end{array}$ & $\begin{array}{l}78 \\
(16)\end{array}$ & $\begin{array}{l}713 \\
(74)\end{array}$ & $\begin{array}{l}769 \\
(30)\end{array}$ \\
\hline Confidence Interval $(\stackrel{+}{-})$ & 20 & 3 & 8 & 10 & 17 & 7 \\
\hline Total Suckers & $\begin{array}{c}273 \\
(132)\end{array}$ & $\begin{array}{l}156 \\
(65)\end{array}$ & $\begin{array}{l}154 \\
(59)\end{array}$ & $\star$ & $\begin{array}{l}116 \\
(59)\end{array}$ & $\begin{array}{l}112 \\
(53)\end{array}$ \\
\hline Confidence Interval $(\stackrel{+}{-})$ & 20 & 7 & 29 & & 26 & 30 \\
\hline Grand Total & $\begin{array}{c}432 \\
(168)\end{array}$ & $\begin{array}{l}234 \\
(82)\end{array}$ & $\begin{array}{l}228 \\
(78)\end{array}$ & & $\begin{array}{l}229 \\
(73)\end{array}$ & $\begin{array}{l}281 \\
(83)\end{array}$ \\
\hline
\end{tabular}

* Insufficient numbers for a population estimate.

The numbers of brown trout in 1972 exceeds the numbers estimated in 1967 , however, the total weight in 1972 remained below the 1967 estimate. This can be explained by the fact that there were 128 browns under 8 inches long in 1972 as compared to 66 in 1967 and by the almost complete lack of fish over 12 inches long (only 4 taken) in 1972 as compared to an estimated 38 over 12 inches long in 1967. The rainbow trout numbers were 98 and 79 per acre in 1967 and 1972, respectively. These estimates include fish 4.0 inches and longer. Combined, the total number of trout was essentially the same in 1972 and 1967, however, the difference in brown trout weight between these two years resulted in the total weight of trout being 30 pounds per acre in 1972 as compared to 36 pounds per acre in 1967. The recovery in trout numbers reflects natural restructuring and stabilization of the stream channel after a 11 construction was completed. Presumably, trout recovery was preceded by recovery of food organisms (aquatic inverterbrates and forage fish). The failure of the pounds of trout to reach preconstruction levels reflects the fact that recovery was 1 imited mainly to the younger, smaller fish segment of the population, and that the lack of older fish is related to the paucity 
of cover from streambank vegetation in association with depths and velocities favorable for larger trout.

In 1970 and 1971, Prickly Pear Creek in the Montana City area was stocked with catchable sized rainbow trout. After 1971, this practice was discontinued. These fish are not included in population estimates (Table 3); their numbers were estimated to be 55 per acre in 1970 and 27 per acre in 1971. Their influence in the wild population was not acertained but probably depressed it somewhat. A negligible number remained in 1972.

The sucker population in 1972 remained 59 percent below preconstruction levels in number and 60 percent in weight (Table 3). These differences are believed to be habitat related, i.e., influenced by such factors as velocities, frequency of pools, periphyton quantities and detritus.

\section{RECOMMENDATIONS}

In situations where stream channels must be altered or relocated, future maintenance problems can be diminished and fish population recovery enhanced if the physical characteristics of the original channel are retained insofar as possible or transmitted to the new channel. Stream discharge and basic sediment load are not permanently changed in highway construction, therefore, it is necessary to maintain the same width, depth, meander wave length and gradient characteristics of the original channel in order to maintain stability in the river system. The final channel design should incorporate needs of fisheries, e.g., pool riffle ratios, bottom configurations or thalweg location.

In implementing this it is recommened that, if a stream must be rechanneled, the new channel be meandered so the original stream length is maintained. As stream channel stability is known to be one of the factors determining game fish carrying capacity, construction machinery should be kept out of the streambed and operated from the bank whenever feasible.

Berms in this study were constructed on a trial basis and were designed without the assistance of a hydraulic specialist. They appear to have potential on streams the size of Prickly Pear or smaller, particularly streams with only moderate spring high water. From the point of view of ultimate game fish habitat (streambank cover) and aesthetics, they are preferred to blanket riprap. Work is needed by a hydrologist on the design and placement of such berms.

Consideration should be given to using materials other than rock for streambank protection, e.g., logs, fiber mats, gabions, or combinations of these.

Emphasis should be placed on devising procedures for stabilizing streambank and improving soil quality to encourage natural seeding and create conditions favorable to the success of transplants rather than emphasizing transplanting to revegetate denuded areas. Existing streambank vegetation should be retained whenever possible.

Any future research should be more intensive than that done for this report. It should be a fully staffed, equipped and funded project and ideally it should have a principal investigator whose only responsibility is the conduct of that project. 
Elser, A.A. 1968. Evaluation of stream improvement structures on Prickly Pear Creek and the East Gallatin River. Job Completion Report, Federal Aid in Fish and Wildlife Restoration Acts, Montana Project No. F-9-R-16. Job $V$.

Elser, A.A. 1969. Evaluation of stream improvement structures on Prickly Pear Creek and the East Gallatin River. Job Completion Report, Federal Aid in Fish and Wildlife Restoration Acts, Montana Project No. F-9-R-17. Job $V$.

Elser, A.A. 1971. Evaluation of stream improvement structures on Prickly Pear Creek and the East Gallatin River. Job Completion Report, Federal Aid in Fish and Wildiife Restoration Acts, Montana Project No. F-9-R-19. Job IIa.

Jensen, I.B. 1971. Recent innovations in roadside revegetation and erosion control. Montana Highway Commission.

Prepared by Dennis L. Workman, Project Biologist Montana Department of Fish and Game

Date August 1974 
